\title{
Analisis Kualitas Keterlingkupan Ruang Terbuka Publik pada Koridor Heritage Jalan Rajawali Surabaya
}

\author{
Sonya Khaerunnisa dan Hertiari Idajati \\ Jurusan Perencanaan Wilayah dan Kota, Fakultas Teknik Sipil dan Perencanaan, \\ Institut Teknologi Sepuluh Nopember (ITS) \\ Jl. Arief Rahman Hakim, Surabaya 60111 Indonesia \\ e-mail: hertiari_idajati@urplan.its.ac.id
}

\begin{abstract}
Abstrak-Ruang publik merupakan aset utama bagi livability dan perekonomian kota. Jalan merupakan ruang publik yang paling mudah diakses. Jalan tak hanya berfungsi sebagai jalur sirkulasi tetapi juga ruang sosial yang dapat merepresentasikan kehidupan dan Identitas Kota. Kota Lama Surabaya berperan penting dalam merepresentasikan identitas Kota Surabaya sebagai "Kota Pahlawan". Pemanfaatan ruang terbuka publik "street" pada Jalan Rajawali di Kawasan Kota Lama Surabaya belum dioptimalkan, padahal berpotensi sebagai city entries atau pintu masuk Kawasan Kota Lama Surabaya. Mengembalikan peran jalan sebagai ruang publik merupakan solusinya yakni dengan mengoptimalkan fungsinya sebagai tempat masyarakat bersosialisasi dan beraktivitas, serta mengintegrasikan kebutuhan pejalan kaki dengan pembangunan lokal. Penelitian ini bertujuan untuk mengetahui kualitas ruang terbuka publik pada koridor heritage Jalan Rajawali, sehingga dapan menjadi bahan pertimbangan alternatif dalam menentukan strategi pengembangan jalan sebagai ruang terbuka publik.
\end{abstract}

Kata Kunci-keterlingkupan, kualitas ruang, ruang publik.

\section{PENDAHULUAN}

$\mathrm{D}$ ALAM penelitian ini penulis memposisikan Jalan Rajawali sebagai City Entries atau jalan masuk kota yakni dalam lingkup Kawasan Kota Lama Surabaya. Hal ini dikarenakan secara administratif dan sistem sirkulasinya, Jalan Rajawali merupakan jalan pertama yang dilalui kendaraan untuk memasuki kawasan inti Kota Lama Surabaya, terutama dari arah pelabuhan tanjung perak. Hal ini juga turut mendukung pelestarian vitalitas Jalan Rajawali terhadap kawasan Kota Lama Surabaya sebagaimana menurut [4], Koridor Jalan Rajawali merupakan bagian dari pola jalan kota lama yang jalan-jalan utamanya sebagai berikut: Heerenstraat (sekarang Jalan Rajawali); Willemstraat (sekarang Jalan Jembatan Merah); Roomkatholikstraat (sekarang Jalan Kepanjen); Boomstraat (sekarang Jalan Branjangan); Schoolstraat (sekarang Jalan Garuda); Werfstraat (sekarang Jalan Penjara); dan Societeitstraat (sekarang Jalan Veteran). Saat ini pun dalam [6], Jalan Rajawali merupakan salah satu zona inti pada kawasan cagar budaya kota lama.

Ditinjau dari nilai sejaranya, Jalan Rajawali memiliki nilai sejarah yang kuat melekat padanya hingga saat ini yang ditandai dengan adanya Taman Jayangrono. Taman yang dibuat sebagai Memorial Park untuk mengenang semangat perjuangan arek-arek Suroboyo dalam pertempuran Surabaya [4]. Tak hanya itu, Jalan Rajawali yang termasuk Kawasan Jembatan Merah memiliki keistimewaan lain. Salah satu keistimewaannya adalah banyaknya bangunan-bangunan bernilai historis yang dibangun pada masa kolonial Belanda dan memiliki gaya arsitektur kolonial modern [6]. Letak administratif, sistem sirkulasi, nilai historis, serta bangunan-bangunan khas kolonial tersebut merupakan potensi awal Jalan Rajawali yang dapat dikembangkan menjadi ruang terbuka publik berupa koridor yang livable (berdaya hidup), sehingga mendorong keinginan masyarakat dan wisatawan untuk beraktifitas dan bersosialisasi di koridor ini.

Namun saat ini disamping potensi yang dimiliki Jalan Rajawali tersebut, terdapat beberapa persoalan-persoalan yang menghambat perkembangannya. Berikut persoalan-persoalan yang terjadi di lingkungan Jalan Rajawali berdasarkan hasil penelitian [5] terkait persoalan yang menyebabkan penurunan vitalitas kawasan, yakni: Banyaknya bangunan yang kumuh, tak terawat serta dibiarkan kosong terbengkalai. Adanya beberapa bangunan baru yang tidak menyesuaikan bentuk dan karakter arsitekturnya dengan bangunan lama di sekitarnya. Kawasan hanya aktif dan ramai dari pagi hingga sore hari, diatas jam 7 malam hanya terlihat aktivitas lalu lintas saja. Di beberapa spot terlihat PKL maupun kios semi permanen yang berjualan. Kendaraan umum yang tidak tertib di terminal bayangan dekat Taman Jayengrono. Kurangnya lahan parkir umum, sehingga banyak kendaraan parkir secara on-street dan menghalangi jalan karena menggunakan hampir setengah dari badan jalan. Hal yang sama juga pernah diutarakan [3], yakni terdapatnya konflik kepentingan antara pejalan kaki dengan pengendara kendaraan bermotor, antara operator kendaraan umum serta pengguna kendaraan lainnya. Hal ini dapat dilihat dari jalur pedestrian yang belum dimanfaatkan secara optimal oleh pejalan kaki dan disalahgunakan sebagai tempat parkir, kebutuhkan lahan parkir secara on street pada keberadaan tanda larangan parkir, serta belum adanya kantong-kantong parkir off street yang tersebar di sepanjang koridor. Persoalanpersoalan seperti inilah yang dapat mengurangi kenyamanan dan keamanan bagi setiap pengguna jalan, yang berdampak pada kurangnya kualitas Jalan Rajawali sebagai ruang terbuka publik.

Berdasarkan potensi dan persoalan diatas, maka strategi pengembangan koridor Jalan Rajawali sebagai ruang terbuka 
publik melalui pendekatan konsep livable street (daya hidup jalan) perlu dilakukan sehingga posisi Jalan Rajawali sebagai City Entries Kawasan Kota Lama yang mendorong perkembangan Kawasan Kota Lama dapat tercipta. Namun sebelum melakukan perumusan strategi diperlukan penelitian terhadap kondisi eksisting kualitas ruang terbuka publik seperti apa yang dimiliki Koridor Heritage Jalan Rajawali dan bagaimana ruang tersebut dimanfaatkan sebagai ruang terbuka publik oleh semua pengguna ruang.

\section{METODE PENELITIAN}

\section{A. Metode Pengumpulan Data}

Metode pengumpulan data primer dilakukan oleh peneliti langsung kepada objek penelitian. Metode ini bertujuan untuk mendapatkan data faktual. Observasi sistematik terhadap kondisi fisik bangunan dan lingkungan dilakukan dengan cara mengamati elemen-elemen yang direkam dalam bentuk foto, penggambaran denah tampak potongan, diagram serta teks atau penjelasan secara deskriptif. Observasi sitematik ini dilakukan pada beberapa elemen perancangan kota yang termasuk kedalam variabel fisik pada penelitian ini. Adapun langkah-langkah yang dilakukan pada teknik observasi sitematik adalah sebagai berikut:

1)Menyiapkan peta dasar penelitian.

2)Pembagian blok amatan pada peta agar memudahkan proses pendataan.

3)Menyiapkan lembar observasi yang sudah berisi kerangka observasi. Meliputi kolom check list, kolom ukuran, kolom keterangan dan tabel penggunaan lahan mikro pada bangunan.

4)Melakukan obervasi, pencatatan, dan pendokumentasian dengan foto.

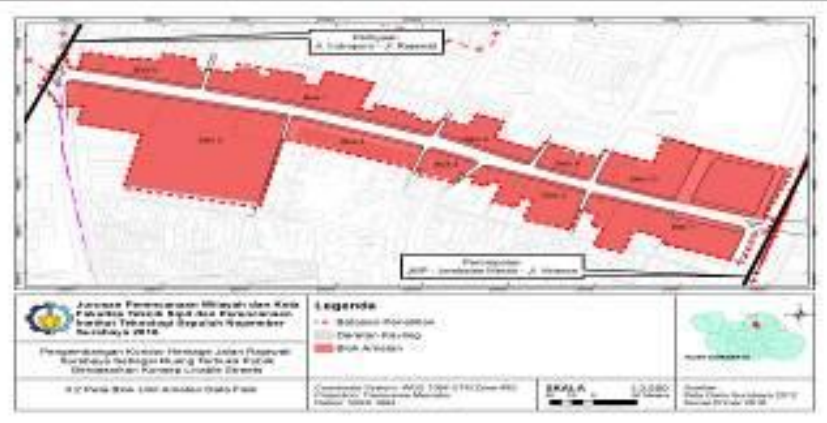

Gambar 1 Peta Blok Amatan

B. Variabel Penelitian

\begin{tabular}{|c|c|c|}
\hline \multicolumn{2}{|c|}{ Variabel } & \multirow{2}{*}{$\begin{array}{l}\text { Definisi oprasional } \\
\text { Ukuran (meter) tinggi elemen dinding } \\
\text { ruang jalan dapat berupa deretan dinding } \\
\text { bangunan, deretan pagar, deretan } \\
\text { pepohonan, atau pun garis semu yang } \\
\text { membatasi/mengarahkan pandangan. }\end{array}$} \\
\hline $\begin{array}{l}\text { Kualitas } \\
\text { Enclosure }\end{array}$ & $\begin{array}{l}\text { Tinggi dinding } \\
\text { Jalan }\end{array}$ & \\
\hline & $\begin{array}{l}\text { Lebar lantai } \\
\text { Jalan }\end{array}$ & $\begin{array}{l}\text { Ukuran (meter) lebar atau jarak antar } \\
\text { bangunan yang melingkupi jalan. Total } \\
\text { dari lebar jalan + lebar trotoar + lebar } \\
\text { setback bangunan. }\end{array}$ \\
\hline & $\begin{array}{l}\text { Garis Setback } \\
\text { Bangunan }\end{array}$ & $\begin{array}{l}\text { Letak garis pemunduran bangunan dari } \\
\text { as jalan. }\end{array}$ \\
\hline
\end{tabular}

Sumber:Hasil Sintesa Pustaka Penulis, 2017

\section{Metode Analisis}

Teknik analisis overlay GIS dan deskriptif kualitatif dengan metode Theoritical Descriptive dan Empirical Descriptive. Metode ini digunakan untuk menggambarkan fenomena yang diteliti secara sistematis, faktual, dan akurat. Dengan menggunakan metode ini, obyek penelitian dianalisis dalam bentuk penjelasan ataupun pengertian.

\section{HASIL DAN PEMBAHASAN}

\section{A. Tahapan Analisis}

Kualitas keterlingkupan ruang koridor Jalan Rajawali didapat berdasarkan proporsi atau rasio antara jarak dan tinggi dinding jalan (street wall). Nilai enclosure (keterlingkupan) yang diperoleh akan menunjukan kualitas dari ruang terbuka publik yang terbentuk pada koridor Jalan Rajawali. Pada penelitian ini analisis kualitas keterlingkupan ruang koridor terbagi menjadi 2 (dua), yakni analisis main enclosure dan second enclosure. Main enclosure diperoleh dari hasil analisis enclosure pada dinding jalan yang bersifat hardscape yakni deretan bangunan disepanjang koridor. Sedangkan second enclosure diperoleh dari hasil analisis pada dinding jalan yang dikombinasikan antara dinding hardscape dengan softscape maupun semu seperti deretan pepohonan, deretan perparkiran, serta deretan elemen lainnya yang membentuk garis semu dan membatasi penglihatan maupun ruang gerak pengguna ruang publik "street".

Tahapan-tahapan yang dilakukan dalam menganalisis kualitas enclosure ruang koridor Jalan Rajawali sebagai berikut:

Tahap 1: Menetapkan garis "Street Wall" atau garis deretan bangunan yang bertindak sebagai dinding dengan nilai (h). Outputnya adalah Peta Kluster Street Wall (Hardscape).

Tahap 2: Membagi koridor Jalan Rajawali menjadi beberapa penggalan jalan berdasarkan dua deret kluster yang saling berhadapan. Outputnya digabung dengan tahap 1.

Tahap 3: Mengelompokan penggalan-penggalan menjadi beberapa tipe penggalan berdasarkan kesamaan dua atau lebih kluster yang membentuk penggalan di tahap 2. Outputnya adalah Peta dan Tabel Tipologi Penggalan.

Tahap 4: Perhitungan nilai main enclosure dan second enclosure dengan ilustrasi. Tahap ini dilakukan pada tiap jenis tipologi pelingkup hardscape sebagai (h) serta mempertimbangkan data total lebar jalan, lebar pedestrian sebagai (d), dan pepohonan sebagai (h) dari pelingkup softscape. Outpunya adalah Tabel Nilai Enclosure Jalan Rajawali.

Tahap 5: Analisis deskriptif kualitatif kualitas keterlingkupan berdasarkan nilai enclosure yang diperoleh pada tiap tipologi penggalan. Outputnya adalah Peta Kualitas Enclosure Koridor Jalan Rajawali. 


\section{B. Analisis Overlay (TAHAP 1)}

Sebelum menentukan nilai main enclosure $\mathrm{d} / \mathrm{h}$ (jarak/tinggi) pada koridor Jalan Rajawali dilakukan teknik analisis overlay terlebih dahulu. Analisis overlay dilakukan untuk mengklasterkan deretan bangunan yang bertindak sebagai street wall pada koridor Jalan Rajawali berdasarkan kesamaan nilai dari data-data peta yang mempengaruhi nilai keterlingkupan ruang. Data-data yang digunakan tersebut adalah sebagai berikut:

1. Peta Ketinggian Bangunan.

Data ketinggian bangunan menunjukan nilai $\mathrm{h}$ dalam perhitungan nilai main enclosure. Deretan bangunan dengan ketinggian yang sama menentukan konsistensi enclosure ruang yang terbentuk.

2. Peta Setback Bangunan.

Data setback bangunan menunjukan perletakan/ garis deret bangunan yang terbentuk. Selain itu setback bangunan juga mempengaruhi nilai $\mathrm{d}$ dalam perhitungan nilai main enclosure

Proses dan tahapan analisis overlay dengan menggunakan softwere ArcGIS 10.1 pada peta ketinggian bangunan dan peta setback bangunan sebagai berikut: Tahapan Raster > Tahapan Overlay > Scale Value > Output Peta Overlay Street Wall (Hardscape). Skoring data ketinggian dan data setback bangunan sebagai berikut:

Tabel 1.

Skoring data ketinggian

\begin{tabular}{|c|c|c|}
\hline & & 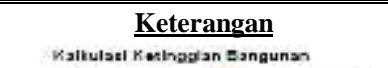 \\
\hline $\begin{array}{l}\text { Data } \\
\text { Ketinggian } \\
\text { Bangunan }\end{array}$ & $\begin{array}{c}\text { Total tinggi } \\
\text { bangunan + } \\
\text { atap } \\
\text { (asumsi } 2 \\
\text { meter) }\end{array}$ & 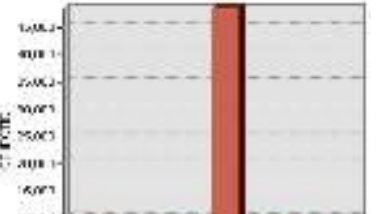 \\
\hline $\begin{array}{l}1 \text { lantai } \\
6 \text { meter }\end{array}$ & 8 meter & \\
\hline $\begin{array}{l}2 \text { lantai } \\
4 \text { meter }\end{array}$ & 6 meter & Sumber: Kalkulasi ArcGIS, 2016 \\
\hline $\begin{array}{l}1 \text { lantai } \\
4 \text { meter }\end{array}$ & 6 meter & $\begin{array}{l}\text { Grafik diatas menunjukan hasil } \\
\text { kalkulasi jumlah objectID }\end{array}$ \\
\hline $\begin{array}{l}2 \text { lantai } \\
8 \text { meter }\end{array}$ & 10 meter & $\begin{array}{l}\text { (bangunan) pada tiap ketinggian } \\
\text { bangunan yang ada di sepanjang }\end{array}$ \\
\hline $\begin{array}{l}3 \text { lantai } \\
12 \text { meter }\end{array}$ & 14 meter & $\begin{array}{l}\text { koridor Jalan Rajawali. Grafik } \\
\text { tersebut menunjukan bahwa }\end{array}$ \\
\hline $\begin{array}{l}4 \text { lantai } \\
16 \text { meter }\end{array}$ & 18 meter & $\begin{array}{l}\text { ketinggian bangunan terbanyak } \\
\text { pada wilayah penelitian adalah }\end{array}$ \\
\hline $\begin{array}{l}1 \text { lantai } \\
3 \text { meter }\end{array}$ & 5 meter & $\begin{array}{l}\text { bangunan dengan tinggi } 10 \text { meter } \\
\text { (skor 5), lalu kedua terbanyak }\end{array}$ \\
\hline $\begin{array}{l}2 \text { lantai } \\
6 \text { meter }\end{array}$ & 8 meter & $\begin{array}{l}\text { adalah } 14 \text { meter (skor } 4 \text { ), ketiga } \\
\text { adalah } 6 \text { meter (skor } 3 \text { ), keempat }\end{array}$ \\
\hline $\begin{array}{l}3 \text { lantai } \\
9 \text { meter }\end{array}$ & 11 meter & $\begin{array}{l}11 \text { meter (skor 2) dan kelima } \\
\text { dengan jumlah yang sangat }\end{array}$ \\
\hline $\begin{array}{l}4 \text { lantai } \\
12 \text { meter }\end{array}$ & 14 meter & $\begin{array}{l}\text { sedikit adalah } 5 \text { meter, } 8 \text { meter, } \\
\text { serta } 18 \text { meter (skor } 1 \text { ). }\end{array}$ \\
\hline
\end{tabular}

Tabel 2.

Data setback bangunan

\begin{tabular}{llc}
\hline \hline $\begin{array}{c}\text { Data Setback } \\
\text { Bangunan }\end{array}$ & Skor & Keterangan \\
\hline 18 meter & 1 & 18 meter, jarak sangat jauh dari nol.
\end{tabular}

\begin{tabular}{lll}
$\begin{array}{lll}\text { 10,12 meter } \\
\text { 3, 4, 5, 6 meter }\end{array}$ & 2 & $\begin{array}{l}\text { 10-12 meter, jarak jauh dari nol. } \\
\text { 1,2 meter }\end{array}$ \\
0 meter & 4 & $\begin{array}{l}\text { 1-2 meter, jarak sudah agak jauh dari nol. } \\
\text { angka nol. } \\
\text { Setback nol sesuai arahan masih mendekati } \\
\text { Kota Lama Surabaya. }\end{array}$ \\
\hline \hline
\end{tabular}

Sumber: Hasil Analisis, 2016

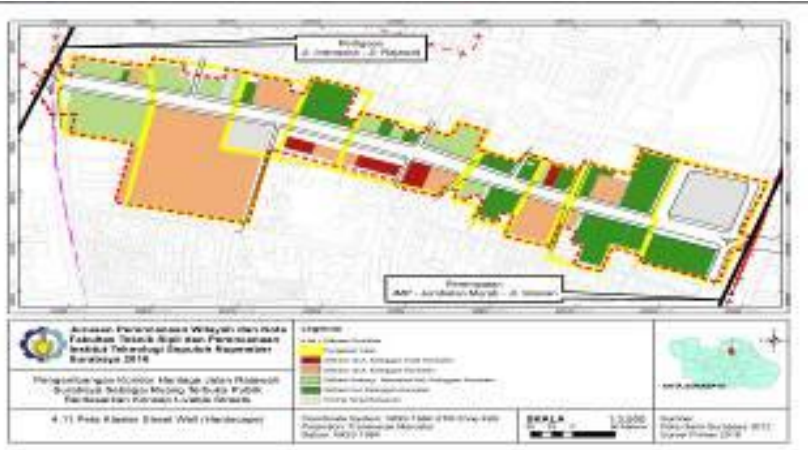

Gambar 2 Peta Hasil Overlay Street Wall

Dapat dilihat pada Gambar 2 terdapat 4 (empat) warna yang menunjukan klaster street wall (hardscape) yang terbentuk. Berikut keterangan dari masing-masing klaster yang muncul:

1. Klaster (1) berwarna merah, menunjukan nilai terendah dari semua klaster. Klaster ini menunjukan deretan bangunan dengan karakter setback yang jauh dari as jalan serta ketinggian bangunan yang tidak konsisten atau memiliki ketinggian yang minoritas dibandingkan bangunan lainnya. Panjang setback pada klaster ini diantaranya adalah 6 meter dan 12 meter. Ketinggian pada klaster ini diantaranya adalah 8 meter, 11 meter dan 18 meter.

2. Klaster (2) warna peach atau salem menunjukan deretan bangunan dengan karakter setback jauh dari as jalan namun memiliki ketinggian bangunan yang konsisten. Panjang setback pada klaster ini diantaranya adalah mulai dari 3 s/d 60 meter. Sedang ketinggiannya adalah 6 meter, 10 meter dan 14 meter.

3. Klaster (3) berwarna hijau muda, menunjukan deretan bangunan dengan karakter setback yang sudah mendekati nol dan ketinggian yang konsisten. Panjang setback pada klaster ini diantaranya adalah 0-6 meter. Sedangkan ketinggiannya adalah 6 meter, 10 meter dan 14 meter.

4. Klaster (4) berwana hijau tua, menunjukan deretan bangunan dengan karakter setback nol dan ketinggian paling konsisten yakni 10 meter.

\section{Analisis Deskriptif Kualitatif (TAHAP 2 s/d 5)}

\section{TAHAP 2}

Kemudian dari peta klaster tersebut dilakukan pembagian penggalan-penggalan jalan berdasarkan 2 (dua) deret klaster yang saling berhadapan. Hal ini dilakukan agar terbentuk penggalan-penggalan jalan dengan karakter street wall yang jelas. Tentu pada beberapan penggalan didalamnya terselip bangunan dengan klaster yang berbeda, namun untuk memudahkan penilaian nilai main enclosure, penentuan deret klaster dilihat dari klaster dominan yang ada pada penggalan 
tersebut. Pada tahap ini dihasilkan 9 (sembilan) penggalan pada koridor Jalan Rajawali.

\section{TAHAP 3}

Dari kesembilan penggalan tersebut ditemukan 5 (lima) tipologi berdasarkan kesamaan tipe 2 (dua) s/d 3 (tiga) klaster yang saling berhadapan atau yang melingkupinya. Yang kemudian nilai enclosure dapat diilustrasikan dan dihitung pada tiap tipologi penggalan.

\section{TAHAP 4}

Penjelasan dan perhitungan dari masing-masing tipologi penggalan dan ilustrasi nilai enclosure-nya yang ditemukan pada Koridor Jalan Rajawali dapat dilihat pada Tabel 3 berikut:

Tabel 3.

Ilustrasi tipologi penggalan

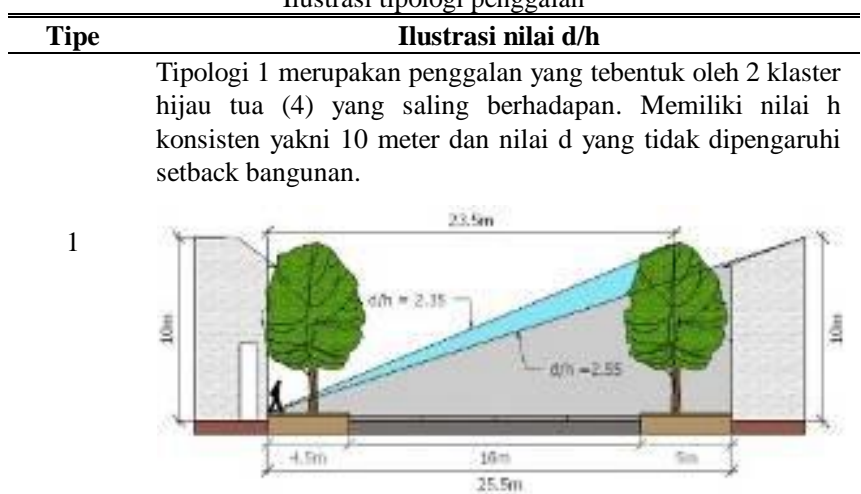

Tipologi 2 merupakan penggalan yang terbentuk oleh 2 klaster hijau muda (3) yang saling berdapan. Memiliki nilai $\mathrm{h}$ konsisten yakni 10 meter namun nilai d dipengaruhi oleh jarak setback bangunan.

2

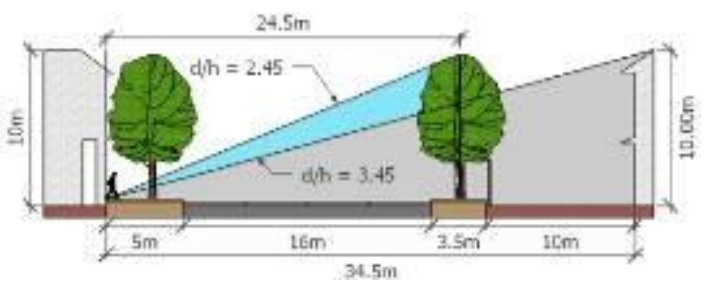

Tipologi 3 merupakan penggalan yang terbentuk oleh klaster (3) hijau muda dan klaster (2) salem yang saling berdapan. Disalah satu sisnya memiliki nilai h konsisten yakni 14 meter dengan setback 6 s/d 0 (nol) meter. Sedang disisi lainya ketinggian konsisten yakni 10 meter namun nilai $d$ dipengaruhi oleh setback yang sangat jauh yakni 60 meter. Sehingga pada tipologi ini nilai main enclosure sukar ditentukan.

3

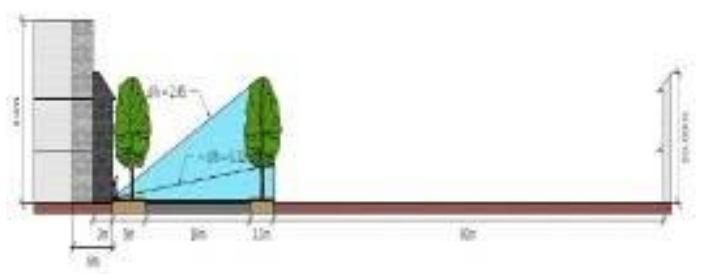

ZOOM

3

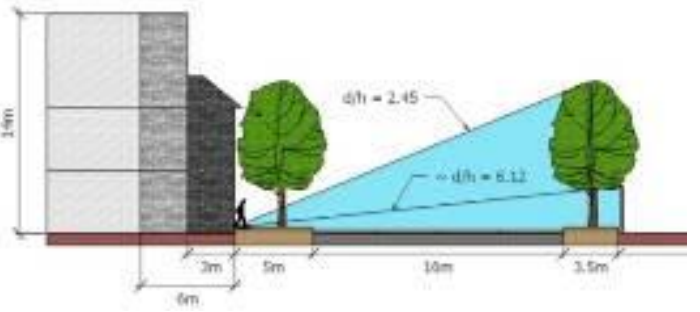

Tipologi 4 merupakan penggalan yang memiliki karakter streetwall yang tidak jelas. Hal ini dikarenakan penggalan ini dibentuk oleh klaster (1) merah ataupun penggalan dengan lebih dari 2 klaster yang berhadapan. Klaster (1) merah sendiri mengindikasikan bahwa deret bangunan tersebut memiliki ketinggian yang tidak konsisten serta setback yang jauh. Sehingga pada tipologi ini nilai main enclosure yang ditemukan bisa sangat beragam dalam satu penggalan.

4
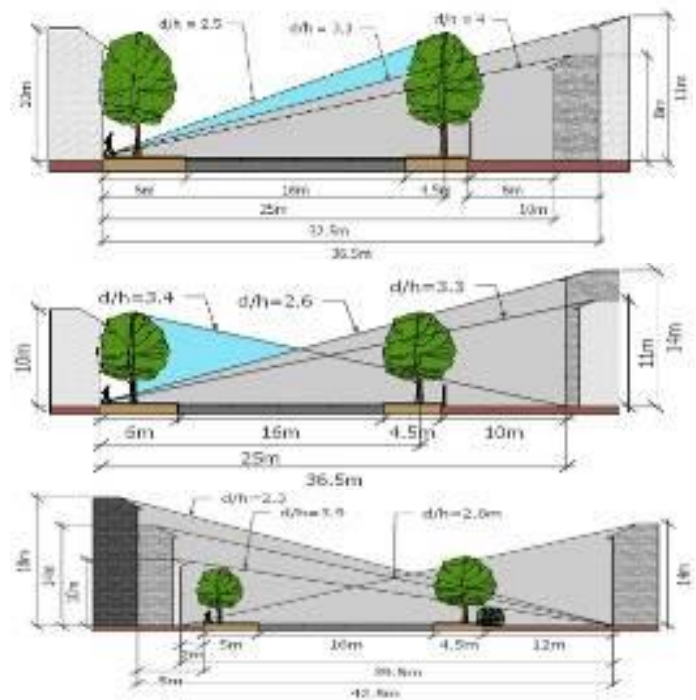

Tipologi 5 merupakan penggalan yang terbentuk dari salah satu klaster yang berhadapan dengan kavling tanpa bangunan. Sehingga penggalan ini tidak memiliki nilai main enclosure karena tidak didilingkupi oleh 2 (dua) elemen hardscape yang berhadapan. Penggalan ini hanya memiliki nilai second enclosure yang dilihat dari $\mathrm{h} / \mathrm{d}$ antara bangunan ke deretan pepohonan atau pun pagar pembatas.
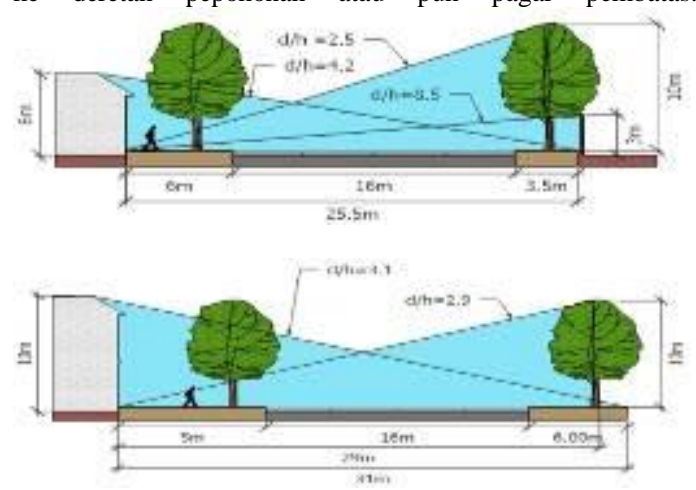
Dari tabel ilustrasi tipologi penggalan diatas didapatkan nilai main enclosure dan second enclosure sebagai berikut:

Tabel 4.

Nilai main enclosure dan second enclosure

\begin{tabular}{lll}
\hline \hline Penggalan & $\begin{array}{c}\text { Nilai Main } \\
\text { Enclosure }\end{array}$ & \multicolumn{1}{c}{ Nilai Second Enclosure } \\
\hline Tipologi 1 & $\mathrm{d} / \mathrm{h}=2,55$ & $\mathrm{~d} / \mathrm{h}=2,35$ \\
Tipologi 2 & $\mathrm{~d} / \mathrm{h}=3,45$ & $\mathrm{~d} / \mathrm{h}=2,45$ \\
Tipologi 3 & $\mathrm{~d} / \mathrm{h}=8,45$ & $\mathrm{~d} / \mathrm{h}=2,45$ \\
Tipologi 4 & $\mathrm{~d} / \mathrm{h}=3,3-4$ & $\mathrm{~d} / \mathrm{h}=2,5$ \\
& $\mathrm{~d} / \mathrm{h}=2,6-3,3$ & $\mathrm{~d} / \mathrm{h}=2,5-3,4$ \\
& $\mathrm{~d} / \mathrm{h}=2,3-3,9$ & $\mathrm{~d} / \mathrm{h}=2,6$ \\
Tipologi 5 & tidak ada & $\mathrm{d} / \mathrm{h}=2,5-2,9$ (pohon) \\
& & $\mathrm{d} / \mathrm{h}=3,1 ; 4,2 ;$ dan 8,5 \\
& & (pagar) \\
\hline \hline
\end{tabular}

Sumber: Hasil Analisis, 2016

\section{TAHAP 5}

Dari nilai $\mathrm{d} / \mathrm{h}$ pada tiap tipologi penggalan yang telah didapatkan, maka dapat diketahui bagaimana kualitas keterlingkupan yang dirasakan pengguna ruang jalan pada tiap penggalan jalan di sepanjang koridor Jalan Rajawali. Pengukuran kualitas menggunakan pustaka menurut beberapa pakar sebagai berikut:

Tabel 5.

Pengukuran kualitas keterlingkupan menurut pustaka

\begin{tabular}{|c|c|c|c|c|c|}
\hline \multicolumn{2}{|c|}{ Nilai $\mathbf{d} / \mathbf{h}$} & $\mathrm{D} / \mathrm{H}=1$ & $\mathrm{D} / \mathrm{H}=\mathbf{2}$ & $\mathrm{D} / \mathrm{H}=\mathbf{3}$ & $\mathrm{D} / \mathrm{H} \geq 4$ \\
\hline \multirow[t]{2}{*}{$\Sigma$} & 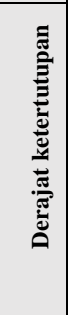 & $\begin{array}{l}\text { Full enclosure, } \\
\text { sangat tertutup, } \\
\text { jika melebihi } \\
\text { batas tersebut } \\
\text { akan timbul } \\
\text { kesan menekan }\end{array}$ & $\begin{array}{c}\text { Therehold } \\
\text { of } \\
\text { enclosure, } \\
\text { merupakan } \\
\text { batas } \\
\text { terendah } \\
\text { untuk } \\
\text { membuat } \\
\text { kesan ruang } \\
\text { tertutup }\end{array}$ & $\begin{array}{l}\text { Minimum } \\
\text { enclosure, } \\
\text { ruang mulai } \\
\text { kehilangan } \\
\text { ketertutupan }\end{array}$ & $\begin{array}{l}\text { Loss of } \\
\text { enclosure, } \\
\text { ruang } \\
\text { kehilangan } \\
\text { kualitas } \\
\text { ketertutupan }\end{array}$ \\
\hline & 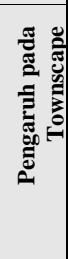 & $\begin{array}{l}\text { Perhatian pada } \\
\text { detil daripada } \\
\text { keseluruhan } \\
\text { bangunan }\end{array}$ & $\begin{array}{c}\text { Melihat } \\
\text { bangunan } \\
\text { sebagai } \\
\text { sebuah } \\
\text { komposisi } \\
\text { keseluruhan } \\
\text { bersama } \\
\text { dengan } \\
\text { detilnya }\end{array}$ & $\begin{array}{l}\text { Melihat } \\
\text { bangunan } \\
\text { dalam } \\
\text { hubungan } \\
\text { dengan } \\
\text { sekelilingnya }\end{array}$ & $\begin{array}{l}\text { Bangunan } \\
\text { sebagai edge } \\
\text { depan } \\
\text { (foreground) } \\
\text { dalam } \\
\text { keseluruhan } \\
\text { pemandangan }\end{array}$ \\
\hline & $\Xi$ & $\begin{array}{c}\text { kualitas ruang } \\
\text { luar dirasakan } \\
\text { keseimbangan } \\
\text { diantara tinggi } \\
\text { bangunan dan } \\
\text { ruang diantara } \\
\text { bangunan }\end{array}$ & \multicolumn{2}{|c|}{$\begin{array}{c}\text { Perletakan bangunan } \mathrm{D} / \mathrm{H}= \\
1,2,3 \text { paling sering } \\
\text { dipergunakan }\end{array}$} & $\begin{array}{l}\text { interaksi } \\
\text { bersama mulai } \\
\text { menghilang } \\
\text { dan interaksi } \\
\text { antara } \\
\text { bangunan } \\
\text { sukar } \\
\text { dirasakan }\end{array}$ \\
\hline & $\bar{\beth}$ & $\begin{array}{c}\text { Proporsi } \\
\text { minimum 1:1 } \\
\text { untuk skala } \\
\text { ruang } \\
\text { pergerakan. } \\
\text { Dimana jika } \\
\text { kurang dari ini } \\
\text { perasaan } \\
\text { terhadap ruang } \\
\text { terasa sempit } \\
\text { dan menakutkan } \\
\text { (claustrophobic) }\end{array}$ & \multicolumn{2}{|c|}{$\begin{array}{c}\text { Proporsi maksimal 2,5:1 } \\
\text { untuk skala ruang pergerakan. } \\
\text { Dimana jika lebih dari ini } \\
\text { perasaan keterlingkupan } \\
\text { lemah, tidak terasa seperti } \\
\text { ruang. }\end{array}$} & \\
\hline
\end{tabular}

Sumber: Hasil Sintesa Pustaka, 2016
Berikut pembahasan hasil ilustrasi pada masing-masing tipologi penggalan:

1. Penggalan Tipologi 1 (Kualitas kuat)

Penggalan ini memiliki nilai main enclosure $\mathrm{d} / \mathrm{h}=2,55$ dan second enclosure $\mathrm{d} / \mathrm{h}=2,35$. Berdasarkan kategori derajat ketertutupan menurut [7], nilai $\mathrm{d} / \mathrm{h}$ pada penggalan ini berada ditengah-tengah antara Therehold of enclosure $(\mathrm{d} / \mathrm{h}=2)$ dan Minimum enclosure $(\mathrm{d} / \mathrm{h}=3)$. Hal ini menunjuan bahwa penggalan ini masih dalam batas kesan ruang tertutup. Dimana pengguna ruang jalan akan melihat bangunan secara menyeluruh bersama dengan detailnya dan juga memperhatikan bangunan dalam hubungan dengan sekelilingnya. Sedang menurut kategori dari [1], penggalan ini masih dalam batas proporsi yang paling sering digunakan untuk membentuk keterlingkupan dimana masih memungkinkan terjadinya interaksi bersama dan dan terasanya interaksi antar bangunan. Sedangkan untuk skala ruang pergerakan sebagaimana menurut kategori [2], penggalan ini masih terasa keterlingkupannya.

Kesimpulannya adalah kualitas keterlingkupan atau ketertutupan pada penggalan ini masih terasa kuat; keseluruhan bangunan dan detilnya serta kesinambungannya dengan lingkungan sekitarnya masih diperhatikan oleh pengguna ruang, sehingga karakter visual dari fasad bangunan sangat mempengaruhi persepsi pengguna ruang terhadap karakter koridor Heritage Jalan Rajawali yang terbentuk; dan sangat memungkinkan terjadinya interaksi bersama oleh pengguna ruang.

2. Penggalan Tipologi 2 (Kualitas lemah)

Penggalan ini memiliki nilai main enclosure $\mathrm{d} / \mathrm{h}=3,45$ dan second enclosure $\mathrm{d} / \mathrm{h}=2,45$. Dilihat dari nilai main enclousure-nya penggalan ini sudah melewati batas minimum enclosure $(\mathrm{d} / \mathrm{h}=3)$ menurut kategori dari Speiregen (1965), namum belum termasuk pada kategori loss of enclosure $(\mathrm{d} / \mathrm{h}=4)$. Hal ini menunjukan bahwa kesan ketertutupan pada penggalan ini masih ada meski terasa terasa lemah. Sedangkan dari nilai second enclosure-nya penggalan ini masih dalam batas keterlingkupan maksimum khususnya dalam skala ruang pergerakan. Secara keseluruhan berdasarkan kategori keterlingkupan menurut [1], pada penggalan ini masih memungkinkan terjadinya interaksi bersama maupun interaksi antara bangunan.

Kesimpulannya adalah kualitas keterlingkupan atau ketertutupan pada penggalan ini masih ada namun terasa lemah; kesan keterlingkupan diperkuat oleh elemen softscape-nya yakni deretan pepohonan; serta masih memungkinkan terjadinya interaksi bersama antar pengguna ruang.

3. Penggalan Tipologi 3 (Kualitas semu)

Penggalan ini memiliki nilai main enclosure $\mathrm{d} / \mathrm{h}=8,45$ dan nilai second enclosure $\mathrm{d} / \mathrm{h}=2,45$. Dilihat dari nilai main enclosure-nya penggalan ini masuk kedalam kategori Loss fo enclosure dimana nilai $\mathrm{d} / \mathrm{h}$ sudah lebih dari 4 
(empat). Sebagaimana yang telah digambarkan oleh [7], pada kategori ini ruang kehilangan kualitas ketertutupannya dan bangunan yang ada hanya berperan sebagai edge depan (foreground) dalam keseluruhan pemandangan koridor. Sedangkan berdasarkan kategori dari Ashihara (1970), pada kategori ini interaksi bersama mulai menghilang dan interaksi antara bangunan sukar dirasakan. Namun dilihat dari nilai second enclosure-nya penggalan ini masih memiliki kesan keterlingkupan khususnya untuk skala ruang pergerakan.

Kesimpulannya adalah kualitas keterlingkupan atau ketertutupan pada penggalan ini mulai menghilang; namun kesan keterlingkupan semu masih bisa dirasakan karena kehadiran elemen softscape-nya yakni deretan pepohonan; kemungkinan terjadinya interaksi bersama antar pengguna mulai menghilang dan interaksi antar bangunan sukar dirasakan. Hal ini membuat kesan Jalan Rajawali sebagai ruang terbuka publik mulai menghilang.

4. Penggalan Tipologi 4 (Kualitas tidak terdefinisi)

Penggalan ini memiliki nilai main enclosure yang beragam dalam satu penggalan, dimana nilainya berkisar antara $\mathrm{d} / \mathrm{h}=2,3$ hingga $\mathrm{d} / \mathrm{h}=3,9$ dan nilai second enclosure dengan nilai berkisar $\mathrm{d} / \mathrm{h}=2,5$ hingga $\mathrm{d} / \mathrm{h}=3,4$. Beragamnya nilai $d / h$ dalam satu penggalan ini menujukan ketidakjelasan atau ketidaktegasan ketertutupan ruang yang terbentuk. Kualitas keterlingkupan ruang menjadi sukar didefinisikan. Kesan ketertutupan mungkin terasa karena ada sebagain yang memiliki nilai $\mathrm{d} / \mathrm{h}$ masih dalam batas maksimal $\mathrm{d} / \mathrm{h}=2,5$ atau $\mathrm{d} / \mathrm{h}=3$. Kemungkinan terjadinya interaksi bersama pun masih ada karena nilai $\mathrm{d} / \mathrm{h}$ masih dibawah 4. Kesimpulannya adalah pada penggalan ini kualitas keterlingkupan atau ketertutupan ruang kemungkinan terasa namun sulit didefinisikan; hal ini tidak menutup kemungkinan terjadinya interaksi bersama antar pengguna ruang.

5. Penggalan Tipologi 5 (Kualitas semu)

Pada penggalan ini hanya terdapat nilai second enclosure yakni $\mathrm{d} / \mathrm{h}=2,5-2,9$ dari elemen pepohonan ke bangunan serta $\mathrm{d} / \mathrm{h}=3,1 ; 4,2 ;$ dan 8,5 dari elemen pagar/tembok pembatas ke bangunan. Dari nilai tersebut menunjukan bahwa kesan keterlingkupan pada penggalan ini masih terasa karena dibentuk oleh elemen pepohonan ke bangunan-nya. Sedangkan dari elemen pagar/tembok pembatas ke bangunan kesan keterlingkupan tidak terasa. Kesimpulannya adalah kualitas keterlingkupan atau ketertutupan pada penggalan ini memiliki kesan keterlingkupan yang terasa semu karena dibentuk dari elemen pepohonan; sedangkan pagar/tembok pembatas tidak mempengaruhi keterlingkupan karena tingginya yang tidak sebanding dengan lebar koridor.

Dari hasil output tahap 5 yakni analisis deskriptif kualitatif kualitas keterlingkupan ruang koridor Jalan Rajawali dapat dilihat pada Peta Hasil Analisis Kualitas Keterlingkupan, ternyata dari 5 tipoloogi penggalan ditemukan 4 kategori berdasarkan kualitas. Dimana penggalan dengan tipologi 3 dan tipologi 5 memliki kualitas enclosure yang sama. Lengkapnya secara keseluruhan berikut hasil penilaian kualitas enclosure pada Jalan Rajawali:

- Kualitas enclosure kuat : Penggalan tipologi 1

Terdiri dari penggalan 4 dan penggalan 6

- Kualitas enclosure lemah : Penggalan tipologi 2

Terdiri dari penggalan 1

- Kualitas enclosure semu : Penggalan tipologi 3 dan 5

Hal ini karena keterlingkupan pada penggalan tipologi 3 dan 5 dibentuk dari elemen softscape-nya saja.

Terdiri dari penggalan 2 dan penggalan 7

- Kualitas enclosure tak terdefinisikan : Penggalan tipologi 4 Terdiri dari penggalan 3 dan penggalan 5

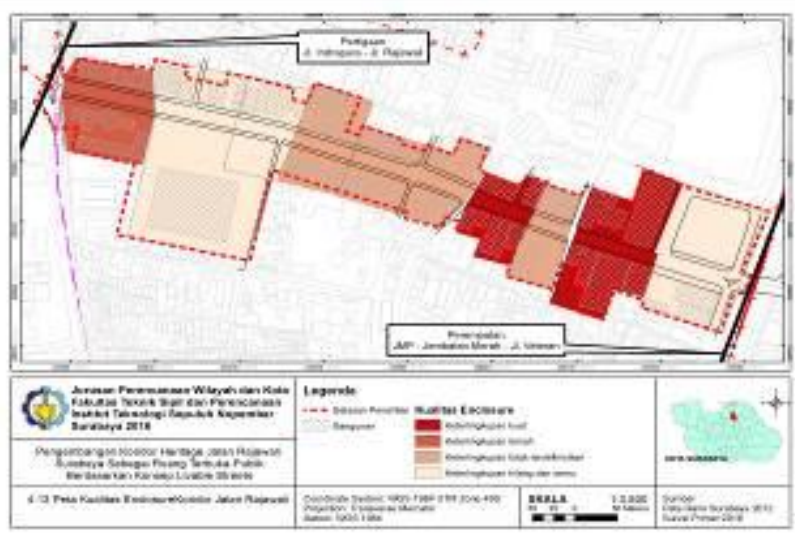

Gambar 3 Peta Hasil Analisis Kualitas Keterlingkupan

\section{KESIMPULAN/RINGKASAN}

Terdapat 4 kategori kualitas enclosure yang dimiliki Koridor Heritage Jalan Rajwali sebagai ruang terbuka publik yakni kualitas enclosure kuat yaitu penggalan 4 dan penggalan 6; kualitas enclosure lemah yaitu pada penggalan 1; kualitas enclosure semu yaitu pada penggalan 2 dan Penggalan 7; serta kualitas enclosure tak terdefinisikan yaitu pada penggalan 3 dan penggalan 5 .

\section{DAFTAR PUSTAKA}

[1] Ashihara, Yoshinobu, 1983, The Aesthetic Townscape, The M.I.T. Press, Cambridge.

[2] A GLC Study. 1978. "An Introduction to Housing Layout". The Architectural Press, London

[3] Danardi, R. W., Antariksa, Hariyani, S. 2010. "Pelestarian Lingkungan dan Bangunan Kuno di Koridor Jalan Rajawali Kota Surabaya". Jurnal Perencanaan Wilayah dan Kota. Malang : Universitas Brawijaya.

[4] Handinoto. 1996. Perkembangan Kota dan Arsitektur Kolonial Belanda di Surabaya (1870-1940), Yogyakarta: Penerbit ANDI Yogyakarta.

[5] Hapsari, II., dan Indradjati, PN. 2015. Strategi Revitalisasi Kawasan Jembatan Merah Surabaya. SAPPK, ITB.

[6] Rencana Strategis Kawasan Kota Lama Surabaya 2012.

[7] Spreiregen, Paul D. 1965. "Urban Design : The Architecture of Towns and Cities". VMcGraw-Hill, New York . 